\title{
The effectiveness of aglime ameliorant to improve soil pH and maize (Zea mays L.) growth and production in Langkat Regency
}

\author{
Erpina Delina Manurung ${ }^{1}{ }^{*}$, Khadijah EL Ramija ${ }^{2}$, and Siti Fatimah Batubara ${ }^{1}$ \\ ${ }^{1}$ Assessment Institute for Agricultural Technology North Sumatra, Land Resources Department, \\ 20143 Medan, Indonesia \\ ${ }^{2}$ Assessment Institute for Agricultural Technology North Sumatra, Sub-Office Head, 20143 Medan, \\ Indonesia
}

\begin{abstract}
Tropical climatic conditions accompanied by high rainfall are supporting factors for soil acidification in Indonesia's drylands. One of the conventional management technologies that are most widely used to improve soil acidity is liming. This study observed the effectiveness of various doses of Aglime ameliorant for improving acid soil and its effect on the growth of maize (Zea mays L.). The study was conducted in Pasar VI Kwala Mencirim Village, Sei Bingai District, Langkat Regency, North Sumatra from June to October 2020. The experimental design of this study was a non-factorial randomized bock design consisted of 7 treatments of Aglime ameliorant dosage with four replications. The results showed that the application of various doses of Aglime ameliorant was able to increase soil $\mathrm{pH}$, height, and maize production which the highest $\mathrm{pH}$ value, height, and production were obtained at Aglime dose of 5 tons $\mathrm{Ha}^{-1}$ (AL 5). The effectiveness of Aglime ameliorant to increase soil $\mathrm{pH}$ is reflected in the relative agronomic effectiveness (RAE) which is overall $>95 \%(101,7-$ 274,5\%) for the tested Aglime dose of 1 to 5 tons per hectare (AL1-AL5).
\end{abstract}

\section{Introduction}

Dryland in Indonesia based on its climatic conditions is divided into wet climate and dry climate dry land with an area of $133,722,331$ and $10,750,881$ hectares, respectively [1]. Approximately $78.71 \%$ of the wet climate dry land area is acidic, while only $23.17 \%$ of the dry climate dry land is acidic. The higher percentage of soil acidification in wet climate dryland was caused by the leaching of alkaline cations due to high rainfall. Utilization of acid dry land as agricultural land has several main obstacles related to low soil fertility including low $\mathrm{pH}$ and organic matter, deficiency of $\mathrm{P}, \mathrm{K}, \mathrm{Ca}$, and $\mathrm{Mg}$ as well as the availability of toxic elements that have the potential to poison crops such as high Al, Fe and Mn [2]. These toxic $\mathrm{Al}$ and $\mathrm{Fe}$ ions will bind macronutrients, especially $\mathrm{P}$ (phosphorus) and $\mathrm{S}$ (sulfur) elements so that they become unavailable to plants even though the amount in the soil is abundant. High soil acidity is also related to the high availability of micro-elements that have the

* Corresponding author: vinadelina1990@gmail.com 
potential to poison plants such as zinc $(\mathrm{Zn})$, copper $(\mathrm{Cu})$, and cobalt $(\mathrm{Co})$ [3], low exchangeable bases, and CEC of base saturations $<50 \%$, the iron, and manganese content is close to toxicity limits and is poor in biotic elements [4].

Maize is one of Indonesia's strategic food crop commodities with a self-sufficiency target in 2017 [5]. The Ministry of Agriculture through the UPSUS program succeeded in increasing maize production in 2015 by $47.48 \%$ in 2017 (28.92 million tons), but this production decreased again in 2019 by $21.88 \%$ to 22.59 million tons [6]. One of the factors that influenced this decline was land-use competition due to limited land because it is known that Indonesia's self-sufficiency target is not only for maize but also for rice and soybeans. One of the available solution is to use suboptimal land such as acid dry land but as previously mentioned, soil acidification in dry land can be an inhibiting factor, so to overcome this, varieties selection and liming are solutions that are commonly used. The variety used in this study was the Bisi18 hybrid maize. [7] reported that the use of the Bisi-18 variety on acid dry land without land quality management had no effect on plant height but had an effect on maize production with a production difference of up to $26.31 \%$ ( 2.4 tons) with the management of biochar applications. To support the production of the varieties used, liming to increase soil $\mathrm{pH}$ is required.

Liming is a conventional technology that is most widely applied to increase soil $\mathrm{pH}$. One of the materials that can be used in liming acid soils besides dolomite is Aglime. Aglime does not contain magnesium like dolomite. To be precise and efficient, the dose can be determined based on the soil Al-dd value while its effectiveness can be achieved through the application of mixing it into the $20 \mathrm{~cm}$ soil layer [8]. The Aglime application will increase the $\mathrm{pH}$ of acidic soil which further has an impact on increasing available soil $\mathrm{P}$, Ca content, and decreasing Al-dd levels in the soil in alluvial lowland soils [8]. The application of lime on acidic dry land was able to increase height, number of filled pods per clump, and soybean production and increase Ca content in the soil [9]. The quality of Aglime is an important factor in increasing the effectiveness of Aglime in increasing acid soil $\mathrm{pH}$ and supporting plant growth. Characteristics to determine the quality of Aglime that are commonly used include purity, fineness, and type of lime material because it is related to the speed of solubility and acid-neutralizing capacity of the Aglime. Based on the description above, this research was carried out to observe the effectiveness of doses of lime ameliorant on improving acid soil $\mathrm{pH}$ and its effect on the growth of maize (Zea mays L.).

\section{Materials and methods}

\subsection{Location and experimental set-up}

The research was conducted on farmer's dry land in Pasar VI Kwala Mencirim Village, Sei Bingai District, Langkat Regency, North Sumatra from June to October 2020. The materials used were hybrid maize seeds, Aglime ameliorant, inorganic fertilizers (SP36, Urea, and $\mathrm{KCl}$ ) were used as the standard treatments. The cultivation tools used were sprayers and hoes rakes and also other tools such as scale, tape measure, sack, plastic, book, and stationery. The devices used to process research data were computers and IBM SPSS 20 statistical software.

The research of the effectiveness of Aglime ameliorant was carried out on acid soils and used maize as an indicator crop. The experimental design of this study was a non-factorial randomized bock design consisted of 7 treatments and 4 replications. The Aglime dose was determined by the soil Al-dd value in a ratio of $1: 1$, which is an average of 1 ton $\mathrm{Ha}^{-1}$ for the

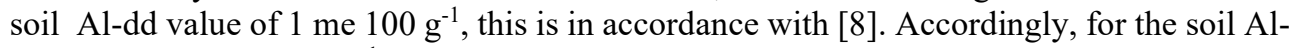
dd value of $2.1 \mathrm{me} 100 \mathrm{~g}^{-1}$ (Table 3), the Aglime doses in this study was determined to be 2 tons Ha. Based on the recommendation Aglime dose $\left(2\right.$ tons $\left.\mathrm{Ha}^{-1}\right)$, the treatment doses was 
determined to be $0.5 ; 1 ; 1.5 ; 2$; and 2.5 times of the recommended dose as shown in Table 1 . The Aglime will be applied 1 week before planting by sprinkled it evenly on each experimental plot.

Table 1. Treatment levels of Aglime dose (ton $\mathrm{Ha}^{-1}$ )

\begin{tabular}{|c|c|c|c|}
\hline No & Treatment & Code & Dose (ton $\mathrm{Ha}^{-1}$ ) \\
\hline 1 & Ag Lime 0 Recommendation & AL0 & 0 \\
\hline 2 & Ag Lime 0.5 Recommendation & AL1 & 2 \\
\hline 3 & Ag Lime 1.0 Recommendation & AL2 & 3 \\
\hline 4 & Ag Lime 1.5 Recommendation & AL3 & 4 \\
\hline 5 & Ag Lime 2.0 Recommendation & AL4 & 5 \\
\hline 6 & Ag Lime 2.5 Recommendation & AL5 & 2 \\
\hline 7 & Standard Aglime & ALS & 2 \\
\hline
\end{tabular}

The number of fertilizers applied to all treatments as basal fertilizers to support optimal plant growth were Urea $350 \mathrm{~kg} \mathrm{Ha}^{-1}$, SP36 $100 \mathrm{~kg} \mathrm{Ha}^{-1}$, and $\mathrm{KCl} 75 \mathrm{~kg} \mathrm{Ha}^{-1}$. Urea fertilizer was applied at 7-10 and 30-35 days after planting (DAP), while SP-36 and $\mathrm{KCl}$ were applied once at 7-10 DAP. The fertilizers were applied by buried next to the plants in a row of plants.

\subsection{Observation and data analysis}

The soil and Aglime parameters observed were initial soil analysis consisted of textures, soil pH $\mathrm{H}_{2} \mathrm{O}$ and $\mathrm{KCl}$, organic $\mathrm{C}$, total $\mathrm{N}, \mathrm{P}, \mathrm{K}$, and available $\mathrm{P}$ (Table 2); initial Aglime analysis consisted of $\mathrm{CaCO}_{3}, \mathrm{CaO}, \mathrm{Al}_{2} \mathrm{O}_{3}+\mathrm{Fe}_{2} \mathrm{O}_{3}, \mathrm{~Pb}, \mathrm{Cd}, \mathrm{Hg}$, As, and fineness on 6 and $60 \mathrm{Mesh}$ (Table 3 ); the increase of soil $\mathrm{pH}$ on $2^{\text {nd }}, 4 \mathrm{t}, 6^{\text {th }}, 8^{\text {th }}$, and $12^{\text {th }}$ week; and the effectiveness of Aglime ameliorant by comparing the RAE value of standard treatment with Aglime treatment. The crop parameters observed were plant height and corn cobs production.

Soil $\mathrm{pH}$ data on the $2^{\text {nd }}, 4^{\text {th }}, 6^{\text {th }}, 8^{\text {th }}$, and $12^{\text {th }}$ weeks are presented in graphical form. Analysis of variance (ANOVA) was used to analyzed data of plant height and maize cobs production. Significances differences between treatments were analyzed using the Duncan Multiple Range Test (DMRT) at a 95\% confidence level. The Relative Agronomy Effectiveness (RAE) value was used to calculate the effectiveness of Aglime. RAE is the ratio between the increase of yield due to the use of a fertilizer with the yield increase with the use of standard fertilizers multiplied by 100 , with the formula [10]:

$$
\mathrm{RAE}=\frac{\text { Yield of tested fertilizer-control }}{\text { Yield of standard fertilizer-control }} \times 100 \%
$$




\section{Results and discussions}

\subsection{The quality of Aglime ameliorant}

The quality test of the Aglime ameliorant was conducted in the Indonesian Oil Palm Research Laboratory. The analysis results presented in Table 2 showed that the Aglime used has met the criteria required in Indonesian National Standard 482:2018. Based on its content, Aglime is mostly used by farmers is divided into calcite and dolomite. The analysis results in table 2 showed that the Aglime tested is calcite, which mostly contains $\mathrm{CaCO}_{3}$, while dolomite contains a mixture of $\mathrm{CaCO}_{3}$ and $\mathrm{MgCO}_{3}$. By the unit weight, $\mathrm{CaCO}_{3}$ has a lower neutralizing capacity than $\mathrm{MgCO}_{3}$, but the dissolution reaction rate is higher [11] following the statement of Stevens and [12] that the solubility of calcite is about 2 times faster than dolomite.

Fineness is one of the important physical criteria related to the effectiveness and efficiency of Aglime, it is shown in Table 2 that $100 \%$ of the Aglime used passes a 60 mesh sieve. [13] stated that the finer the Aglime is applied, the faster the reaction between Aglime and soil in increasing soil $\mathrm{pH}$ so the amount of lime needed will reduce. [14] added that the dissolution reaction of Aglime is influenced by the surface area where the greater the surface area per unit weight of Aglime in contact with the soil, the solubility and effectiveness in increasing the $\mathrm{pH}$ also increases.

Table 2. The results of the Aglime ameliorant quality analysis

\begin{tabular}{|c|c|c|c|c|}
\hline Parameters & Method & Unit & Value & $\begin{array}{c}\text { Value-based on } \\
\text { INS 482:2018 }\end{array}$ \\
\hline $\mathrm{CaCO}_{3}$ & Calculation & $\%$ & 98.77 & - \\
\hline $\mathrm{CaO}$ & AOAC.917.01.2016 & $\%$ & 55.35 & Min 44 \\
\hline $\mathrm{Al}_{2} \mathrm{O}_{3}+\mathrm{Fe}_{2} \mathrm{O}_{3}$ & AOAC.964.01.2016 & $\%$ & 0.48 & Max 1.5 \\
\hline $\mathrm{Pb}$ & AAS & $\mathrm{ppm}$ & $<0.06$ & Max 50 \\
\hline $\mathrm{Cd}$ & AAS & $\mathrm{ppm}$ & $<0.002$ & Max 10 \\
\hline $\mathrm{Hg}$ & AAS & $\mathrm{ppm}$ & $<0.01$ & Max 1 \\
\hline $\mathrm{As}$ & AAS & $\mathrm{ppm}$ & $<0.002$ & Max 10 \\
\hline Fineness $6 \mathrm{Mesh}$ & Sieve & $\%$ & 100.00 & - \\
\hline Fineness $60 \mathrm{Mesh}$ & Sieve & $\%$ & 100.00 & Min 55 \\
\hline
\end{tabular}

*) Based on the dry weight

\subsection{Soil analysis}

The initial soil analysis was conducted in the Soil and Plant Laboratory of Assessment Institute for Agricultural Technology (AIAT) North Sumatra. The results of the initial soil analysis are listed in the Table 3 and the criteria are determined according to [15]. The soil $\mathrm{pH}$ is acidic (4.76), so the application of Aglime to increase soil $\mathrm{pH}$ is required. Soil organic $\mathrm{C}$ content, total $\mathrm{N}$, available $\mathrm{P}, \mathrm{K}, \mathrm{Ca}$, and $\mathrm{Mg}$ were high, moderate, low, very low and low respectively while the micronutrients such as $\mathrm{Cu}$, and $\mathrm{Zn}$ were sufficient; $\mathrm{Mn}$ was very high, $\mathrm{Fe}$ was high, and CEC was moderate. The soil texture was loamy sand (https://www.nrcs.usda.gov/wps/portal/nrcs/detail/soils/survey/?cid=nrcs142p2 054167). 
Table 3. The results of initial soil analysis

\begin{tabular}{|c|c|c|}
\hline Parameters & Value & Analysis Method \\
\hline Organic C (\%) & 3.22 & IK 5.0 (Spectrophotometer) \\
\hline Total N (\%) & 0.32 & IK 6.0 (Kjeldahl) \\
\hline P Bray I (ppm) & 8.71 & IK 7.0 (Spectrophotometer) \\
\hline $\mathrm{K}-\mathrm{dd}(\mathrm{me} / 100 \mathrm{~g})$ & 0.33 & IK 8.0 AAS \\
\hline $\mathrm{pH}$ & 4.34 & IK 3.0 (Electrometry) \\
\hline Al-dd (me/100 g) & 2.10 & IK 4.0 (Titrimetry) \\
\hline $\mathrm{Ca}(\mathrm{me} / 100 \mathrm{~g})$ & 1.03 & IK 8.0 (AAS) \\
\hline $\mathrm{Mg}(\mathrm{me} / 100 \mathrm{~g})$ & 0.40 & IK 8.0 (AAS) \\
\hline $\mathrm{Cu}(\mathrm{ppm})$ & 1 & IK 8.0 (AAS) \\
\hline $\mathrm{Zn}(\mathrm{ppm})$ & 6 & IK 8.0 (AAS) \\
\hline Mn (ppm) & 31 & IK 8.0 (AAS) \\
\hline $\mathrm{Fe}(\mathrm{ppm})$ & 31 & IK 8.0 (AAS) \\
\hline $\begin{array}{c}\text { Textures } \\
\text { Sand }(\%) \\
\text { Silt }(\%) \\
\text { Clay }(\%)\end{array}$ & $\begin{array}{c}81.71 \\
16.00 \\
2.29\end{array}$ & IK 9.0 (Hydrometer) \\
\hline CEC (me/100 g) & 20.60 & Direct distillation \\
\hline
\end{tabular}

\subsection{Soil pH measurements}

Soil $\mathrm{pH}$ is an early indicator of soil fertility that describes the level of soil acidity and alkalinity which its value determined by the concentration of $\mathrm{H}^{+}$ions in the soil. As a master soil variable, $\mathrm{pH}$ has a very important influence on various soil properties (physical, chemical, biological) and reactions that contribute to plant growth and production [16]. Neutral soil $\mathrm{pH}$ ranging from 6.5 to 7.5 is the best $\mathrm{pH}$ value for plants because in this $\mathrm{pH}$ range there is an equilibrium between macro and micronutrients in the soil. [17] explained that soil $\mathrm{pH}$ affects nutrient availability either directly by increasing the availability of $\mathrm{Mn}$, $\mathrm{Zn}, \mathrm{Zu}$, and $\mathrm{Fe}$ and decreasing $\mathrm{N}, \mathrm{K}, \mathrm{Ca}, \mathrm{Mg}$, and $\mathrm{S}$ at low $\mathrm{pH}$ or indirectly increasing the availability of $\mathrm{P}$ and $\mathrm{B}$ at low and high $\mathrm{pH}$. In addition, high concentrations of toxic elements such as $\mathrm{Al}$ in acid soils can affect the performance of plant roots to absorb nutrients thereby limiting plant growth and production [18].

It is shown in Table 4 that Aglime application affects increasing soil $\mathrm{pH}$ on the $2^{\text {nd }}, 4^{\text {th }}$, $6^{\text {th }}, 8^{\text {th }}$ and $12^{\text {th }}$ week. The highest increase in soil $\mathrm{pH}$ in the $2^{\text {nd }}$ week was found in AL4 and AL5 treatments of 1.73 and 2.43 respectively from the initial soil $\mathrm{pH}$ to 6.07 and 6.77 with slightly acid and neutral categories. Table 4 showed that up to the $12^{\text {th }}$ week, the highest soil $\mathrm{pH}$ value was shown in AL4 (6.98) and AL5 (7.12) treatments with a total increase of 60.82 and $64.05 \%$ respectively compared to the initial soil $\mathrm{pH}$ value. The increasing of soil $\mathrm{pH}$ by 
Aglime occurs because the $\mathrm{H}^{+}, \mathrm{Fe}^{2+}, \mathrm{Al}^{3+}, \mathrm{Mn}^{4+}$, and $\mathrm{Cu}^{2+}$ ions at the adsorption site are replaced by $\mathrm{Ca} 2+$ and or $\mathrm{Mg} 2+$ ions depending on the type of lime [19].

Table 4. Soil $\mathrm{pH}$ measurement on $2^{\text {nd }}, 4^{\text {th }}, 6^{\text {th }}, 8^{\text {th }}$, and $12^{\text {th }}$ week after Aglime application

\begin{tabular}{|c|c|c|c|c|c|}
\hline \multirow{2}{*}{ Treatment } & & \multicolumn{4}{|c|}{$\mathbf{p H}$} \\
\cline { 2 - 6 } & $\mathbf{2}^{\text {nd }} \mathbf{w e e k}$ & $\mathbf{4}^{\text {th }} \mathbf{w e e k}$ & $\mathbf{6}^{\text {th }}$ week & $\mathbf{8}^{\text {th }}$ week & $\mathbf{1 2}^{\text {th }}$ week \\
\hline AL0 & 4.34 & 4.34 & 4.34 & 4.34 & 4.34 \\
\hline AL1 & 5.36 & 5.44 & 5.8 & 5.91 & 5.95 \\
\hline AL2 & 5.66 & 5.82 & 6.5 & 6.6 & 6.67 \\
\hline AL3 & 6.03 & 6.73 & 6.5 & 6.55 & 6.59 \\
\hline AL4 & 6.07 & 6.79 & 6.8 & 6.9 & 6.98 \\
\hline AL5 & 6.67 & 6.97 & 7.0 & 7.05 & 7.12 \\
\hline ALS & 5.84 & 5.72 & 6.0 & 6.2 & 6.41 \\
\hline
\end{tabular}



Fig 1. Graph of pH soil changes

\subsection{Plant height}

It was found that plant height was significantly affected by the application of Aglime at weeks 2, 4, 6, and 8 compared to the control treatment (Table 5). Increasing the Aglime dose in this study positively increased the height of the maize plant where the average value of the maize plant height in the application of Aglime doses of 4 and 5 tonnes $\mathrm{Ha}^{-1}$ for the entire observation time was not significantly different. Generally, the application of Aglime (AL1AL4) showed a higher height than the control but not for the standard Aglime treatment. The effect of Aglime application on higher maize height was also reported by other researchers such as $[20,21,22]$. The increase in the availability of most of the nutrients needed by maize due to the increase in $\mathrm{pH}$ by liming has a positive impact on the growth of maize plants [23]. Increasing the $\mathrm{pH}$ value of the soil in the range of 6-7 as in this study contributes to the increase and absorption of plant nutrients such as $\mathrm{N}$ and $\mathrm{P}$, which each function to increase vegetative growth and plant roots [24]. 
Table 5. Analysis results of maize plant height in Week After Planting (WAP)

\begin{tabular}{|c|c|c|c|c|}
\hline \multirow{2}{*}{ Treatment } & \multicolumn{4}{|c|}{ Height } \\
\cline { 2 - 5 } & $\mathbf{2}$ WAP & $\mathbf{4}$ WAP & $\mathbf{6}$ WAP & 8 WAP \\
\hline AL0 & $11,25 \mathrm{c}$ & $62.75 \mathrm{~d}$ & $108.75 \mathrm{e}$ & $200 \mathrm{~d}$ \\
\hline AL1 & $13.25 \mathrm{~b}$ & $70.50 \mathrm{c}$ & $115.75 \mathrm{~d}$ & $205 \mathrm{c}$ \\
\hline AL2 & $13.87 \mathrm{~b}$ & $72.25 \mathrm{c}$ & $120.50 \mathrm{c}$ & $212.50 \mathrm{~b}$ \\
\hline AL3 & $14.37 \mathrm{a}$ & $74.75 \mathrm{~b}$ & $124.25 \mathrm{~b}$ & $216.25 \mathrm{~b}$ \\
\hline AL4 & $14.75 \mathrm{a}$ & $78.25 \mathrm{a}$ & $128.25 \mathrm{a}$ & $216.87 \mathrm{a}$ \\
\hline AL5 & $15 \mathrm{a}$ & $78.75 \mathrm{a}$ & $128.25 \mathrm{a}$ & $220.62 \mathrm{a}$ \\
\hline ALS & $13.62 \mathrm{~b}$ & $72.25 \mathrm{c}$ & $117.50 \mathrm{~d}$ & $208.75 \mathrm{c}$ \\
\hline
\end{tabular}

Note: This means follow different letter (s) along the same column are statistically different based DMRT test at $\mathrm{p}=0.05$

\subsection{Maize production (cobs without husks)}

It was revealed that maize production was significantly affected by the application of Aglime to the soil. The highest maize production was found in the AL5 treatment (Aglime 5 tons $\mathrm{Ha}^{-1}$ ) with a total production of 6337.5 tons $\mathrm{Ha}^{-1}$ while the lowest production was found in the control treatment of 4312.5 tons $\mathrm{Ha}^{-1}$. The average maize production in AL1 treatment was not significantly different from the control (AL0) and standard Aglime (ALS) treatment but was significantly different from other treatments (AL2-AL5). The average maize production is at 1 ton $\mathrm{Ha}^{-1}$ (AL1). Aglime dose treatment was not significantly different from the 2 and 3 ton $\mathrm{Ha}^{-1}$ Aglime dose treatment (AL2 and AL3) also the standard lime treatment 1 ton $\mathrm{Ha}^{-1}$ (ALS) but significantly different from the maize production average on treatment doses 4 and 5 ton Ha-1 (AL4 and AL 5). Compared to the average maize production in the control treatment, the application of Aglime was able to increase the average maize production by $2.50-10.31 \%$.

According to the data in Table 6, the increase in the Aglime dose actually increases maize production, this is related to the effect of increasing $\mathrm{pH}$ on increasing the availability of $\mathrm{K}$ macronutrient which plays an important role in improving growth and increasing crop yield [25]. Increasing the Aglime dose will increase the concentration of Ca nutrients in the soil. $\mathrm{Ca}$ nutrient has an antagonistic interaction with $\mathrm{K}$ nutrient so that the balance of its concentration in the soil needs to be considered so as not to interfere with each other [26]. However, in this study, it was shown that the antagonism of the two nutrients did not occur, which may be due to the soil texture which is dominated by sand (Table 3). Putra [27] explained that due to the difference in valence, the increase in $\mathrm{Ca}$ due to lime application contributed to $\mathrm{K}$ fixation in soils with high clay content.

Table 6. Analysis results of maize production (cobs without husks)

\begin{tabular}{|c|c|c|}
\hline Treatment & Production $\mathrm{kg} \mathrm{plot}^{-1}$ & Production $\mathrm{kg} \mathrm{Ha}^{-1}$ \\
\hline AL0 & $8.6 \mathrm{~d}$ & $4321.5 \mathrm{~d}$ \\
\hline AL1 & $10.1 \mathrm{c}$ & $5062.5 \mathrm{c}$ \\
\hline
\end{tabular}




\begin{tabular}{|c|c|c|}
\hline Treatment & Production kg plot & Production $\mathrm{kg} \mathrm{Ha}^{-1}$ \\
\hline AL2 & $10.3 \mathrm{c}$ & $5137.5 \mathrm{c}$ \\
\hline AL3 & $10.8 \mathrm{c}$ & $5375 \mathrm{c}$ \\
\hline AL4 & $11.4 \mathrm{~b}$ & $5687.5 \mathrm{~b}$ \\
\hline AL5 & $12.7 \mathrm{a}$ & $6337.5 \mathrm{a}$ \\
\hline ALS & $10.1 \mathrm{c}$ & $5050 \mathrm{c}$ \\
\hline
\end{tabular}

Note: Means follow different letter (s) along the same column are statistically different based DMRT test at $\mathrm{p}=0.05$

\subsection{Relative agronomic effectiveness (RAE)}

Fertilizer effectiveness which is calculated as relative agronomic effectiveness (RAE) is based on the vegetative growth rate, production, and/or quality of agricultural products [28]. Expressed as a percentage, the relative agronomic effectiveness (RAE) value is the ratio between the increasing yield due to the application of the tested fertilizer and the increasing yield with the application of a standard or recommended fertilizers. A fertilizer is declared to be agronomic effective if it has a relative agronomic effectiveness value above the relative agronomic effectiveness value of standard fertilizer (100\%) [29]. Table 7 shows the RAE value $>100 \%$ for all Aglime application doses with the highest RAE value (274.5\%) was shown in the AL5 treatment ( 5 tons $\left.\mathrm{Ha}^{-1}\right)$. This indicated that the AL5 treatment in this study was the most effective in increasing soil $\mathrm{pH}$ which supported the growth and production of maize.

Table 7. Measurement results of Relative Agronomic Effectiveness (\%)

\begin{tabular}{|c|c|}
\hline Treatment & Relative Agronomic Effectiveness (\%) \\
\hline AL0 & - \\
\hline AL1 & 101.7 \\
\hline AL2 & 111.8 \\
\hline AL3 & 144 \\
\hline AL4 & 186 \\
\hline AL5 & 274.5 \\
\hline ALS & 100 \\
\hline
\end{tabular}

The effectiveness of lime to increase soil $\mathrm{pH}$ is determined by various internal factors including source, purity, characteristics, fineness, dosage, and composition as well as external factors such as method, time, frequency, and depth of application [30]. The effect of the dose is clearly seen in table 7 where the more Aglime is applied, the higher the RAE value. The effect of the dose is also supported by the characteristics of the Aglime used. Regarding it's characteristics which is difficult to dissolve, the fineness of Aglime and incubation time affect the increase in soil $\mathrm{pH}$. This statement is supported by [14] in their research that the increase in soil $\mathrm{pH}$ is in line with the increase in incubation time and lime fineness where the value of the increase is greater in Aglime than dolomite. The same pattern was found in the results of this study, as shown in table 4, it can be seen that there was an 
increase in soil $\mathrm{pH}$ with a change of $0.45-1.01$ after 10 weeks (comparison of soil $\mathrm{pH}$ data from 2 to $12 \mathrm{WAP}$ ). The fineness of the Aglime used in the study that passed the 60 mesh sieve indicates that the lime has a large surface area in contact with the soil when applied and according to [14] has the potential to provide a maximum $\mathrm{pH}$ increase value.

\section{Conclusions}

The test results showed that the application of Aglime was able to increase the $\mathrm{pH}$ value of acidic soil to slightly acidic and neutral. The increase in $\mathrm{pH}$ due to the application of Aglime in this study further gave higher maize production and plant height compared to treatments of control and standard Aglime application. The relative value of agronomic effectiveness (RAE) for all treatments of tested agricultural lime doses was $>100 \%$. Based on the parameters tested, the dose of 5 tons $\mathrm{Ha}^{-1}$ is the dose that gives the maximum contribution on soil $\mathrm{pH}$, growth, and maize production on acid dry land.

Acknowledgments. The authors would like to thank the Minister of Agriculture for giving the confidence to test the effectiveness of fertilizers in North Sumatra following PERMENTAN No. $318 / \mathrm{Kpts} / \mathrm{OT} .050 / 5 / 2018$ concerning the appointed institution to test the effectiveness of organic, inorganic, and soil repair fertilizers. We also thank the farmers, communities, and technicians who have participated and contributed by providing land, time, and energy to make the Aglime effectiveness test a success.

\section{References}

1. S. Ritung, E. Suryani, D. Subardja, Sukarman, K. Nugroho, Suparto, Hikmatullah, A. Mulyani, C. Tafakresnanto, Y. Sulaeman, R.E. Subandiono, Wahyunto, Ponidi, N. Prasodjo, U. Suryana, H. Hidayat, A. Priyono, W. Supriatna. IAARD Press. Ed 2015, 98 $\mathrm{p}(2014)$

2. A. Wijanarko, A. Taufiq. Buletin Palawija. 7 \& 8, 39-50 (2004)

3. M. Nazir, Syakur, Muyassir. Jurnal Ilmiah Mahasiswa Pertanian Unsyiah. 2, 1 (2017)

4. Dariah, N. Heryani. Jurnal Sumberdaya Lahan Edisi Khusus, 1-16 (2014)

5. A.A.Sulaiman, P. Simatupang, I. Las, E. Jamal, Hermanto, I.K. Kariyasa, Syahyuti, S. Sumaryanto, Suwandi, K. Subagyono. IAARD Press. 1, 1-272 (2018)

6. Kementerian Pertanian. Rencana Strategis Kementerian Pertanian 2020-2024 (Kementerian Pertanian, Jakarta, 2020).

7. N. Sutrisna, Y. Surdianto, A. Ruswandi. CR Journal 5, 2 (2019)

8. D. Krisnawati, C. Bowo. Berkala Ilmiah Pertanian, 2, 1 (2019)

9. Subandi, A. Wijanarko. Penelitian Pertanian Tanaman Pangan, 32, 3 (2013)

10. A. D. Mackay, J. K. Syers, P. E. H. Gregg. New Zealand Journal of Agricultural Research, 27, 2 (1984)

11. A. Pagani, A.P. Mallarino. Soil Sci. Soc. Am. J., 76, 1877-1886 (2012)

12. J.J. Stevens, R.W. Blanchar. Soil Sci. Soc. Am. J. 56, 3, 967-972 (1992)

13. Rosmaiti, M.P. Syukri, F. Azmul. Agrosamudra 4, 1 (2017)

14. J.D. Jones, A. Mallarino. Soil Sci. Soc. Am. J, 82, 271-282 (2018)

15. Balai Penelitian Tanah. Petunjuk Teknis Edisi 2 Analisis Kimia Tanah, Tanaman, Air, dan Pupuk (Balai Penelitian Tanah, Bogor, 2009).

16. D. Neina. Applied and Environmental Soil Science. 2019, 1-9 (2019)

17. B. Siswanto. Buana Sains 18, 2 (2018) 
18. S.R. Dalimunthe, A.B. Arif, I.B. Jamal. Jurnal Pertanian Tropik 2, 3 (2015)

19. T. Ameyu. JEES 9, 2 (2019)

20. M. Lolani, V.H. Kabambe. Afr. J. Agric. Res. 16, 6 (2020)

21. Yulianti, J. Hadie, C. Nisa. Jurnal Daun 3, 2 (2016)

22. L.A. Noza, H. Yetti, M.A. Khoiri. JOM Faperta 1, 2 (2014)

23. P.A. Opala. Advances in Agriculture. 2017, 1-5, (2016)

24. W. Saputro, R. Sarwitri, P.S.V.R. Ingesti. VIGOR: Jurnal Ilmu Pertanian Tropika dan Subtropika 2, 2 (2017)

25. C. Hafsi, A. Debez, C. Abdelly. Acta Physiol Plant 36, 5 (2014)

26. E.N. Ginting, A. Sutandi, B. Nugroho, L.T. Indriyati. J. Tanah Lingk., 15, 2 (2013)

27. I.A. Putra, H. Hanum. Journal of Islamic Science and Technology 4, 1 (2018)

28. D. A. Suriadikarta, D. Setyorini, W. Hartatik. Balai Penelitian Tanah, $1^{\text {st }}$ Ed, 1-50 (2004)

29. M. Subandi, S. Hasani, W. Satriawan. Jurnal Agrista, 20, 3 (2016)

30. A. Nduwumuremyi. RRJAAS, 2, 4 (2013) 